\title{
SISTEM PENDUKUNG KEPUTUSAN PENENTUAN SUPPLIER BAHAN BANGUNAN MENGGUNAKAN METODE SMART (SIMPLE MULTI ATTRIBUTE RATING TECHNIQUE) PADA TOKO BINTANG KERAMIK JAYA
}

\author{
Irwan ukkas $^{1)}$, Heny Pratiwi $^{2)}$, Dessy Purnamasari ${ }^{2)}$ \\ ${ }^{1,2,3}$ Teknik Informatika, STMIK Widya Cipta Dharma \\ ${ }^{1,2,3}$ Jl. Prof. M. Yamin No. 25, Samarinda, 75123 \\ E-mail: irwan212@yahoo.com ${ }^{1)}$,heny@henypratiwi.com ${ }^{2)}$,dessy17m@gmail.com ${ }^{3)}$
}

\begin{abstract}
ABSTRAK
Sistem Pendukung Keputusan (SPK) adalah sistem yang dapat membantu seseorang dalam mengambil keputusan yang akurat dan tepat sasaran. Banyak permasalahan yang dapat diselesaikan dengan menggunakan SPK, salah satunya adalah Penentuan Supplier Bahan Bangunan dengan menggunakan bantuan metode SMART (Simple Multi Attribute Rating Technique) Pada Toko Bintang Keramik Jaya.

Tujuan dari penelitian ini adalah untuk menghasilkan Sistem Pendukung Keputusan Penentuan Supplier Bahan Bangunan Menggunakan Metode SMART (Simple Multi Attribute Rating Technique) Pada Toko Bintang Keramik Jaya dengan harapan seleksi Supplier secara obyektif. Dengan menggunakan bahasa pemrograman Visual Basic 6.0 dan databasenya menggunakan Microsoft Access. Dalam penelitian ini, teknik pengumpulan data yang digunakan adalah studi pustaka, observasi dan wawancara.

Hasil dari penelitian ini adalah dibuatnya sistem pendukung keputusan untuk mengetahui Penentuan Supplier yang layak, dipertimbangkan, dan belum terpilih untuk dipilih. Pengguna dapat menginputkan data Supplier, data kriteria, data subkriteria. Kemudian sistem akan mencari solusi dengan metode SMART. Setelah keputusan didapatkan, maka sistem akan menampilkan keputusan tersebut.
\end{abstract}

Kata Kunci: Sistem Pendukung Keputusan, Penentuan Supplier Bahan Bangunan, Simple Multi Attribute Rating Technique

\section{PENDAHULUAN}

Mengambil Keputusan adalah salah satu dari kegiatan manusia yang paling mendasar dalam kehidupan seharihari. Dalam proses pengambilan keputusan manusia seringkali dihadapkan pada banyak alternatif yang dapat dipilih, sehingga untuk suatu permasalahan beberapa pembuat keputusan dapat mengambil keputusan yang berbeda.

Toko Bintang Keramik Jaya adalah sebuah toko bangunan yang melakukan transaksi penjualan bahan bangunan kepada pelanggan dan transaksi pembelian bahan bangunan dari supplier. Pemenuhan kebutuhan persediaan bahan bangunan dilakukan dengan pemesanan ke berbagai supplier. Tidak semua supplier memenuhi kriteria yang ditetapkan Toko Bintang Keramik Jaya, maka harus dilakukan seleksi dan menuntut bagian pembelian untuk menentukan supplier yang tepat. Penentuan supplier masih dilakukan secara manual sehingga menghabiskan banyak waktu, ditambah lagi tidak adanya kriteria yang jelas dari Toko Bintang Keramik Jaya menyebabkan proses penentuan supplier cenderung dilakukan secara subyektif. Berbagai masalah dalam penentuan supplier adalah masalah pemberian kualitas barang dari supplier, kepantasan harga dengan kualitas barang yang dibeli sehingga menjadi salah satu syarat harga kompetitif, jangka waktu pembayaran yang tidak tentu, dan pelayanan untuk mengirimkan barang sesuai kesepakatan.
Untuk mengatasi hal tersebut maka dibutuhkan sebuah sistem yang membantu proses penentuan supplier melalui kriteria-kriteria yang ditentukan. Metode yang digunakan untuk sistem pendukung keputusan penentuan supplier ini adalah dengan metode SMART (Simple Multi Attribute Rating Technique) yang membantu pihak pimpinan toko Toko Bintang Keramik Jaya untuk melakukan pengambilan keputusan penentuan Supplier dengan lebih cepat dan akurat.

\section{RUANG LINGKUP PENELITIAN}

\subsection{Rumusan Masalah}

Berdasarkan latar belakang dari penelitian ini, maka rumusan masalah yang dapat dikemukan adalah “ Bagaimana membangun Sistem Pendukung Keputusan Penentuan Supplier Bahan Bangunan Menggunakan Metode SMART (Simple Multi Attribute Rating Technique) Pada Toko Bintang Keramik Jaya? ”.

\subsection{Batasan Masalah}

Adapun batasan-batasan dari masalah yang akan diteliti dalam pembuatan Sistem Pendukung Keputusan menggunakan Metode SMART pada Toko Bintang Keramik Jaya sebagai berikut : 
1. Sistem ini dibangun dengan menggunakan bahasa pemrograman Microsoft Visual Basic 6.0 dan Microsoft Access 2007 untuk pembuatan databasenya.

2. Metode yang digunakan dalam pembuatan sistem pendukung keputusan ini adalah SMART (Simple Multi Attribute Rating Technique).

3. Kriteria yang digunakan dalam penelitian ini sesuai dengan kententuan Pimpinan Toko :

(1) Kualitas Barang (40\%)

a. Sangat Berkualitas (100)

b. Berkualitas (50)

c. Kurang Berkualitas (0)

(2) Harga Kompetitif (30\%)
a. Sangat Kompetitif (100)
b. Kompetitif (80)
c. Kurang Kompetitif (40)

(3) Waktu pembayaran (20\%)
a. $\geq 12$ bulan $(100)$
b. $\geq 4-<12$ bulan (80)
c. $0-<4$ bulan $(20)$

(4) Pelayanan $(10 \%)$
a. Baik (100)
b. Cukup (80)
c. Kurang (0)

\section{BAHAN DAN METODE}

Adapun bahan dan metode algoritma yang digunakan dalam aplikasi ini adalah:

\subsection{Sistem Pendukung Keputusan}

Menurut Kusrini (2007), sistem pendukung keputusan adalah salah satu jenis sistem sistem yang sangat popular dikalangan manajemen perusahaan adalah Sistem Pendukung Keputusan. Sistem Pendukung Keputusan ini merupakan suatu informasi yang diharapkan dapat membantu manajemen dalam proses pengambilan keputusan. Hal yang perlu ditekankan disini adalah bahwa keadaaan Sistem Pendukung Keputusan bukan untuk menggantikan tugas-tugas pimpinan, tetapi untuk menjadi sasaran pendukung bagi mereka.

Sistem pendukung keputusan merupakan implementasi yang telah diperkenalkan oleh ilmu-ilmu seperti operation research dan management science. Hanya bedanya adalah bahwa jika dahulu untuk mencari penyelesaian masalah yang dihadapi, kini telah menawarkan kemampuan untuk menyelesaikan persoalan yang sama dalam waktu yang relatif singkat.

Sistem pendukung keputusan adalah serangkaian kelas tertentu dari sistem informasi terkomputerisasi yang mendukung kegiatan pengambilan keputusan bisnis dan organisasi. Suatu DSS yang dirancang dengan benar adalah suatu sistem berbasis perangkat lunak interaktif yang dimaksudkan untuk membantu para pengambil keputusan.

\subsection{Pemodelan Dalam Sistem Pendukung Keputusan}

Menurut Kusrini (2007), saat melakukan pemodelan dalam pembangunan Sistem Pendukung Keputusan dilakukan langkah-langkah sebagai berikut:

1. Studi Kelayakan (Intelligence)
Pada langkah ini, sasaran ditentukan dan dilakukan pencarian prosedur, pengumpulan data, identifikasi masalah, identifikasi kepemilikan masalah, klasifikasi masalah, hingga akhirnya terbentuk sebuah pernyataan masalah. Kepemilikan masalah berkaitan dengan bagian apa yang akan dibangun oleh DSS dan apa tugas dari bagian tersebut sehingga model tersebut bisa relevan dengan kebutuhan si pemilik masalah.

2. Perancangan (Design)

Pada tahapan ini akan diformulasikan model yang akan digunakan dan kriteria-kriteria yang ditentukan. Setelah itu, dicari alternatif model yang bisa menyelesaikan permasalahan tersebut. Langkah selanjutnya adalah memprediksi keluaran yang mungkin. Kemudian, ditentukan variabel-variabel model.

3. Pemilihan (Choice)

Setelah pada tahap design ditentukan berbagai alternatif model beserta variabel-variabelnya, pada tahapan ini akan dilakukan pemilihan modelnya, termasuk solusi dari model tersebut. Selanjutnya, dilakukan analisis sensitivitasnya, yakni dengan mengganti beberapa variabel.

4. Membuat SPK

Setelah menentukan modelnya, berikutnya adalah mengimplementasikannya dalam aplikasi SPK.

\subsection{Struktur Sistem Pendukung Keputusan}

Menurut Kusrini (2007) keputusan yang diambil untuk menyelesaikan suatu masalah dilihat dari struktur masalahnya terbagi menjadi 3 (tiga) yaitu:

1. Keputusan Terstruktur (Structured Decision)

Keputusan yang dilakukan secara berulang-ulang dan bersifat rutin. Prosedur pengambilan keputusan sangatlah jelas. Keputusan tersebut terutama dilakukan pada manajemen tingkat bawah. Misalnya, keputusan pemesanan dan keputusan penagihan piutang.

2. Keputusan Semi Terstruktur (Semi Structured Decision)

Keputusan yang memiliki dua sifat. Sebagian keputusan bisa ditangani oleh komputer dan yang lain tetap harus dilakukan oleh pengambilan keputusan. Prosedur dalam pengambilan keputusan tersebut secara garis besar sudah ada, tetapi ada beberapa hal yang masih memerlukan kebijakan dari pengambil keputusan. Biasanya keputusan semacam ini diambil oleh manajer level menengah dalam suatu organisasi. Contoh keputusan jenis ini adalah pengevaluasian kredit, penjadwalan produksi dan pengendalian persediaan.

3. Keputusan Tak Terstruktur (Unstructured Decision) Keputusan yang penangananya rumit karena tidak terjadi berulang-ulang atau tidak selalu terjadi. Menurut pengalaman dan berbagai sumber yang bersifat eksternal.

Keputusan tersebut umumnya terjadi pada manajemen tingkat atas. Contohnya adalah keputusan untuk pengembangan teknologi baru, keputusan untuk bergabunng dengan perusahaan lain dan perekrutan eksekusif. 
3.4 SMART (Simple Multi Attribute Rating Tehnique)

Menurut Kustiyahningsih, Anamisa, dan Syafa'ah (2013), SMART merupakan metode pengambilan keputusan yang multiatribut. Teknik pembuatan keputusan multiatribut ini digunakan untuk membantu stakeholder dalam memilih antara beberapa alternatif. Setiap alternatif terdiri dari sekumpulan atribut dan setiap atribut mempunyai nilai-nilai, nilai ini dirata-rata dengan skala tertentu. Setiap atribut mempunyai bobot yang menggambarkan seberapa penting ia dibandingkan dengan atribut lain. Dengan SMART pembobotan atribut dilakukan dengan dua langkah yaitu:

1. Mengurutkan kepentingan suatu atribut dari level terburuk ke level terbaik.

2. Membuat perbandingan rasio kepentingan setiap atribut dengan atribut lain dibawahnya.

SMART lebih banyak digunakan karena kesederhanaanya dalam merespon kebutuhan pembuat keputusan dan caranya menganalisa respon. Analisa yang terlibat adalah transparan sehingga metode ini memberikan pemahaman masalah yang tinggi dan dapat diterima oleh pembuat keputusan. Pembobotan pada SMART menggunakan skala antara 0 sampai 1, sehingga mempermudah perhitungan dan perbandingan nilai pada masing-masing alternatif.

Model yang digunakan dalam SMART:

$u\left(a_{i}\right)=\sum_{J=1}^{m} w_{j} u_{i}\left(a_{i}\right), \quad i=1,2, \ldots m$

Keterangan:

$w_{j} \quad=$ nilai pembobotan kriteria ke-j dan $k$ kriteria

$u\left(a_{i}\right)=$ nilai $u t i l i t y$ kriteria ke-i untuk kriteria ke-i

Pemilihan keputusan adalah mengidentifikasi mana dari $\mathrm{n}$ alternatif yang mempunyai nilai fungsi terbesar.

\subsection{Teknik SMART (Simple Multi Attribute Rating Tehnique)}

Menurut Kustiyahningsih, Anamisa, dan Syafa'ah (2013), Teknik SMART sebagai berikut:

1. Langkah 1: menentukan jumlah kriteria

2. Langkah 2: sistem secara default memberikan skala 0-100 berdasarkan prioritas yang telah diinputkan kemudian dilakukan normalisasi.

Normalisasi $=\frac{w_{j}}{\sum w_{j}}$

Keterangan : $w_{j}$ : bobot suatu kriteria

$\sum w_{j}:$ total bobot semua kriteria

3. Langkah 3: memberikan nilai kriteria untuk setiap alternatif.

4. Langkah 4: hitung nilai utility untuk setiap kriteria masing-masing.

$$
u_{i}\left(a_{i}\right)=100 \frac{\left(C_{\text {outi }}-C_{\min }\right)}{\left(C_{\text {max }}-C_{\text {min }}\right)} \%
$$

Keterangan :

$u_{i}\left(a_{i}\right)$ : nilai utility kriteria ke-1 untuk kriteria ke-i

$C_{\max }$ : nilai kriteria maksimal

$C_{\text {min }}$ : nilai kriteria minimal

$C_{\text {out } i}$ : nilai kriteria ke-i

5. Langkah 5: hitung nilai akhir masing-masing.

\subsection{Contoh Kasus}

$$
u\left(a_{i}\right)=\sum_{J=1}^{m} w_{j} u_{i}\left(a_{i}\right),
$$

Suatu perusahaan A ingin mempromosikan jabatan tertentu. Akan tetapi pihak PSDM (Pengembangan Sumber Daya Manusia) kesulitan dengan banyaknya kriteria-kriteria yang disediakan oleh perusahaan tersebut.

Tabel 1. Kriteria Pengalaman/Masa Kerja

\begin{tabular}{|c|c|c|c|}
\hline No & Kriteria & Nilai & Bobot \\
\hline 1 & $\begin{array}{c}25-35 \\
\text { tahun }\end{array}$ & 100 & \\
\cline { 1 - 3 } 2 & $\begin{array}{c}24-25 \\
\text { tahun }\end{array}$ & $75 \%$ \\
\cline { 1 - 3 } 3 & $\begin{array}{c}5-14 \\
\text { tahun }\end{array}$ & 50 & \\
\cline { 1 - 3 } 4 & $\begin{array}{c}<4 \\
\text { tahun }\end{array}$ & 0 & \\
\hline
\end{tabular}

\begin{tabular}{|c|c|c|c|}
\hline $\begin{array}{l}\mathrm{N} \\
\mathrm{o}\end{array}$ & $\begin{array}{c}\text { Kriteri } \\
\mathrm{a}\end{array}$ & $\begin{array}{c}\text { Nila } \\
\text { i }\end{array}$ & $\begin{array}{c}\text { Bobo } \\
t\end{array}$ \\
\hline 1 & $\mathrm{~A}$ & 100 & \multirow{5}{*}{$40 \%$} \\
\hline 2 & $B$ & 80 & \\
\hline 3 & $\mathrm{C}$ & 60 & \\
\hline 4 & $\mathrm{D}$ & 40 & \\
\hline 5 & $E$ & 10 & \\
\hline
\end{tabular}

Tabel 2. Kriteria Nilai Prestasi Kerja

Tabel 3. Kriteria Kesehatan

\begin{tabular}{|c|c|c|c|}
\hline $\begin{array}{c}\text { N } \\
\text { o }\end{array}$ & Kriteria & Nilai & Bobot \\
\hline 1 & $\begin{array}{c}\text { Sangat } \\
\text { Baik }\end{array}$ & 100 & \multirow{2}{*}{$10 \%$} \\
\cline { 1 - 3 } 2 & Baik & 80 & \multirow{2}{*}{$10 \%$} \\
\hline 3 & Cukup & 60 & \\
\cline { 1 - 3 } 4 & Kurang & 40 & \\
\cline { 1 - 2 } 5 & $\begin{array}{c}\text { Sangat } \\
\text { Kurang }\end{array}$ & 10 & \\
\hline
\end{tabular}


Tabel 4. Kriteria Usia

\begin{tabular}{|c|c|c|c|}
\hline $\begin{array}{l}\mathrm{N} \\
\mathrm{O}\end{array}$ & Kriteria & Nilai & Bobot \\
\hline 1 & $>40$ tahun & 100 & \multirow{5}{*}{$5 \%$} \\
\hline 2 & $35-41$ tahun & 75 & \\
\hline 3 & $28-34$ tahun & 50 & \\
\hline 4 & $21-27$ tahun & 25 & \\
\hline 5 & $<21$ tahun & 0 & \\
\hline
\end{tabular}

Tabel 5. Kriteria Tanggung Jawab

\begin{tabular}{|l|l|c|l|}
\hline No & Kriteria & Nilai & Bobot \\
\hline 1 & Ya & 100 & \multirow{2}{*}{$10 \%$} \\
\hline 2 & Tidak & 0 & \\
\hline
\end{tabular}

Tabel 6. Kriteria Nilai Fisik

\begin{tabular}{|l|c|c|l|}
\hline No & Kriteria & Nilai & Bobot \\
\hline 1 & Ya & 100 & \multirow{2}{*}{$5 \%$} \\
\hline 2 & Tidak & 0 & \\
\hline
\end{tabular}

Langkah-langkah pengerjaan SMART (Simple Multi Attribute Rating Technique) sebagai berikut:

1. Ketentuan dalam mempromosikan jabatan adalah sebagai berikut:

1) $\geq 80-100:$ layak

2) $\geq 60-<80:$ dipertimbangkan

3) $0-<60$ : tidak layak

4) Seleksi Uji Coba 1 adalah karyawan yang sudah diberikan nilai dari perusahaan.

2. Nilai didapat dari kriteria utama dan sub kriteria sebagai berikut :

1) Kriteria pengalaman/masa kerja memiliki sub kriteria 25 - 35 tahun yang memiliki nilai 100 , sub kriteria $24-25$ tahun yang memiliki nilai 75 , sub kriteria 5 - 14 tahun yang memiliki nilai 50 , dan sub kriteria $<4$ tahun yang memiliki nilai 0 .

2) Kriteria nilai prestasi kerja memiliki sub kriteria A yang memiliki nilai 100, sub kriteria B yang memiliki nilai 80 , sub kriteria $C$ yang memiliki nilai 60 , sub kriteria D yang memiliki nilai 40 , dan sub kriteria E yang memiliki nilai 10 .

3) Kriteria kesehatan memiliki sub kriteria sangat baik yang memiliki nilai 100, sub kriteria baik yang memiliki nilai 80 , sub kriteria cukup yang memiliki nilai 60 , sub kriteria kurang yang memiliki nilai 40, dan sub kriteria sangat kurang yang memiliki nilai 10 .

4) Kriteria usia memiliki sub kriteria $>40$ tahun yang memiliki nilai 100 , sub kriteria $35-41$ tahun yang memiliki nilai 75 , sub kriteria $28-34$ tahun yang memiliki nilai 50, sub kriteria $21-27$ yang memiliki nilai 25 , dan sub kritetia $<21$ tahun yang memiliki nilai 0 .

5) Kriteria tanggung jawab memiliki sub kriteria ya yang memiliki nilai 100 , dan sub kriteria tidak yang memiliki nilai 0 .

6) Kriteria nilai fisik memiliki sub kriteria tidak cacat yang memiliki nilai 100 , dan sub kriteria cacat yang memiliki nilai 0 .
3. Normalisasi didapat dari:

1) Kriteria pengalaman / masa kerja memiliki bobot $30 \%$

2) Kriteria nilai prestasi kerja memiliki bobot $40 \%$

3) Kriteria kesehatan memiliki bobot $10 \%$

4) Kriteria usia memiliki bobot $5 \%$

5) Kriteria tanggung jawab memiliki bobot $10 \%$

6) Kriteria nilai fisik memiliki bobot 5\%

Rumus normalisasi adalah :

Normalisasi $=\frac{w_{j}}{\sum w_{j}}$

Keterangan:

$w_{j} \quad=$ nilai pembobotan kriteria $\mathrm{ke}-\mathrm{j}$ dan $k$ kriteria:

$u\left(a_{i}\right)=$ nilai $u t i l i t y$ kriteria ke-i untuk kriteria ke-i

Cara mendapatkan nilai normalisasi sebagai berikut:

1) Normalisasi $=\frac{30}{100}=0,3$

Keterangan : 30 adalah nilai bobot kriteria pengalaman / masa kerja.

100 adalah nilai bobot keseluruhan

2) Normalisasi $=\frac{40}{100}=0,4$

Keterangan : 40 adalah nilai bobot kriteria nilai prestasi kerja.

100 adalah nilai bobot keseluruhan

3) Normalisasi $=\frac{10}{100}=0,1$

Keterangan : 10 adalah nilai bobot kriteria kesehatan.

100 adalah nilai bobot keseluruhan

4) Normalisasi $=\frac{5}{100}=0,05$

Keterangan : 5 adalah nilai bobot kriteria usia 100 adalah nilai bobot keseluruhan

5) Normalisasi $=\frac{10}{100}=0,1$

Keterangan : 10 adalah nilai bobot kriteria tanggung jawab

100 adalah nilai bobot keseluruhan

6) Normalisasi $=\frac{5}{100}=0,05$

Keterangan : 5 adalah nilai bobot kriteria nilai fisik

100 adalah nilai bobot keseluruhan 
4. Cara mencari nilai utility adalah sebagai berikut: Rumus nilai utility :

$$
u_{i}\left(a_{i}\right)=100 \frac{\left(C_{\text {outi }}-C_{\min }\right)}{\left(C_{\max }-C_{\min }\right)} \%
$$

\section{Keterangan :}

$u_{i}\left(a_{i}\right)$ : nilai utility kriteria ke-1 untuk kriteria ke-i $C_{\max }$ : nilai kriteria maksimal

$C_{\min }$ : nilai kriteria minimal

$C_{\text {out } i}$ : nilai kriteria ke-i

Cara mendapatkan nilai utility sebagai berikut:

1) Kriteria pengalaman / masa kerja

$$
\begin{aligned}
& u_{i}\left(a_{i}\right)=100 \frac{(75-0)}{(100-0)} \% \\
& u_{i}\left(a_{i}\right)=100 \frac{(75)}{(100)} \% \\
& u_{i}\left(a_{i}\right)=100.0,75 \% \\
& u_{i}\left(a_{i}\right)=75
\end{aligned}
$$

2) Kriteria nilai prestasi kerja

$$
\begin{aligned}
& u_{i}\left(a_{i}\right)=100 \frac{(80-10)}{(100-10)} \% \\
& u_{i}\left(a_{i}\right)=100 \frac{(70)}{(90)} \% \\
& u_{i}\left(a_{i}\right)=100.0,78 \% \\
& u_{i}\left(a_{i}\right)=77,78
\end{aligned}
$$

3) Kriteria kesehatan

$$
\begin{aligned}
& u_{i}\left(a_{i}\right)=100 \frac{(100-10)}{(100-10)} \% \\
& u_{i}\left(a_{i}\right)=100 \frac{(90)}{(90)} \% \\
& u_{i}\left(a_{i}\right)=100.1 \% \\
& u_{i}\left(a_{i}\right)=100
\end{aligned}
$$

4) Kriteria usia

$$
\begin{aligned}
& u_{i}\left(a_{i}\right)=100 \frac{(100-0)}{(100-0)} \% \\
& u_{i}\left(a_{i}\right)=100 \frac{(100)}{(100)} \% \\
& u_{i}\left(a_{i}\right)=100.1 \% \\
& u_{i}\left(a_{i}\right)=100
\end{aligned}
$$

5) Kriteria Tanggung Jawab

$$
\begin{aligned}
& u_{i}\left(a_{i}\right)=100 \frac{(100-0)}{(100-0)} \% \\
& u_{i}\left(a_{i}\right)=100 \frac{(100)}{(100)} \% \\
& u_{i}\left(a_{i}\right)=100.1 \% \\
& u_{i}\left(a_{i}\right)=100
\end{aligned}
$$

6) Kriteria Tanggung Jawab

$$
\begin{aligned}
& u_{i}\left(a_{i}\right)=100 \frac{(100-0)}{(100-0)} \% \\
& u_{i}\left(a_{i}\right)=100 \frac{(100)}{(100)} \%
\end{aligned}
$$

$$
\begin{aligned}
& u_{i}\left(a_{i}\right)=100.1 \% \\
& u_{i}\left(a_{i}\right)=100
\end{aligned}
$$

5. Nilai Hasil didapat dari :

Rumus :

Hasil $=$ Nilai utility $\mathrm{x}$ normalisasi

1) Kriteria pengalaman / masa kerja Hasil $=75 \times 0,3$

$$
=22,5
$$

2) Kriteria nilai prestasi kerja

Hasil $=77,78 \times 0,4$

$$
=31,11
$$

3) Kriteria Kesehatan

Hasil $=100 \times 0,1$

$$
=10
$$

4) Kriteria Usia

Hasil $=100 \times 0,05$

$$
=5
$$

5) Kriteria tanggung jawab

Hasil $=100 \times 0,1$

$$
=10
$$

6) Kriteria nilai fisik

Hasil $=100 \times 0,05$

$$
=0,05
$$

6. Cara mencari nilai hasil akhir sebagai berikut :

$$
\begin{aligned}
u\left(a_{i}\right) & =\sum_{J=1}^{m} w_{j} u_{i}\left(a_{i}\right), \\
\text { Hasil } & =22,5+31,11+10+5+10+5 \\
& =83,61
\end{aligned}
$$

Dari hasil uji coba pada 4 pegawai hanya 2 orang yang dinyatakan layak, karena mendapatkan nilai tinggi pada bobot $1(30 \%)$ dan bobot $2(40 \%)$. Sementara 2 lainnya yang dinyatakan tidak layak dan dipertimbangkan dikarenakan nilai pada bobot 1 dan 2 kurang mendapatkan hasil yang maximal. Maka dapat disimpulkan bahwa bobot sangatlah berpengaruh dalam perhitungan ini.

\subsection{Microsoft Visual Basic 6.0}

Subari dan Yustanto (2008), Visual Basic selain disebut sebagai bahasa pemrograman (Language Program), juga sering disebut sebagai sarana (Tool) untuk menghasilkan program-program aplikasi berbasis windows.

Setelah Visual Basic dijalankan, akan muncul sebuah layar. Layar ini adalah lingkungan pengembangan aplikasi Visual Basic yang nantinya akan digunakan untuk membuat program-program aplikasi dengan Visual Basic. 


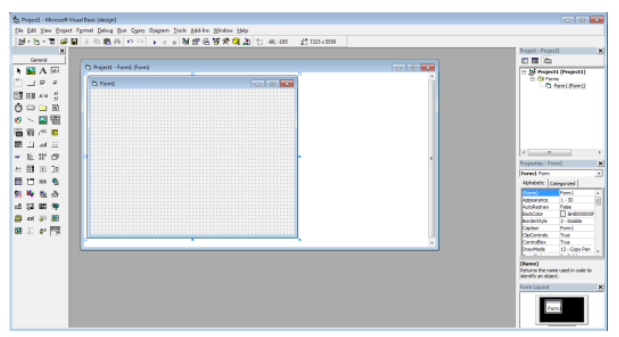

Gambar 1. Lingkungan Visual Basic 6.0

Layar Visual Basic adalah suatu lingkungan besar yang terdiri dari beberapa bagian-bagian kecil yang kesemuanya memiliki sifat.

Visual Basic IDE (Interface Development Envirotment) adalah tampilan antarmuka program dengan pengguna yang sudah bersifat GUI (Grafical User Interface), menyajikan banyak kemudahan bagi para programmer untuk membuat aplikasi. Tampilan IDE Visual Basic sebagai berikut:

1) Мепи Bar

Menu Bar berfungsi memberikan kemudahan kepada pengguna dalam memilih aksi-aksi yang umum seperti mengedit, mengkopi atau menjalankan program. Beberapa fungsi yang ada di Menu Bar juga tersedia di Toolbar.

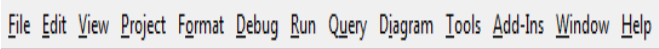

Gambar 2. Tampilan Menu Bar pada Visual Basic 6.0

2) Form

Form di Visual Basic adalah media tempat kita membuat aplikasi atau antarmuka yang bersifat GUI (Grafical User Interface). Kita dapat menempelkan berbagai macam objek atau kontrol di atas form tersebut.

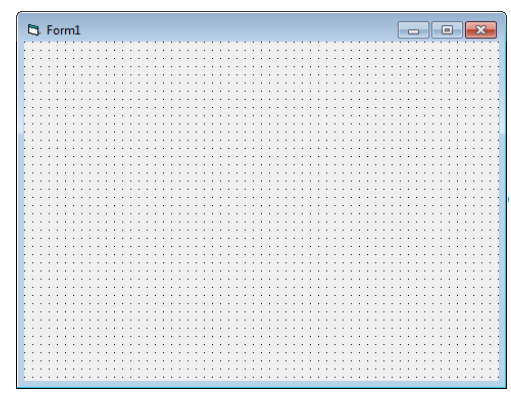

Gambar 3. Tampilan form pada Visual Basic 6.0

3) Standart Toolbar

Standart Toolbar berfungsi menyediakan fasilitas yang umum digunakan oleh para programmer ketika mendesain aplikasi, seperti membuka atau menyimpan file, menjalankan program dan lain-lain.

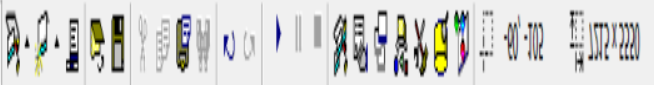

\section{Gambar 4. Tampilan Standart toolbar pada Visual Basic 6.0}

\section{4) Project Window}

Dengan adanya project window, kita dapat melihat form atau objek apa saja yang ada di dalam satu proyek, dan kita dapat menghapusnya dari project window tersebut.

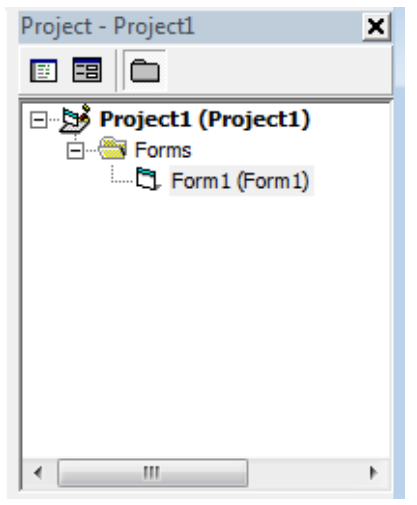

\section{Gambar 5. Tampilan project window pada Visual Basic 6.0}

5) Toolbox

Toolbox berisi komponen-komponen standar yang diperlukan dalam membuat aplikasi seperti textbox, label, combo box dan lain-lain.

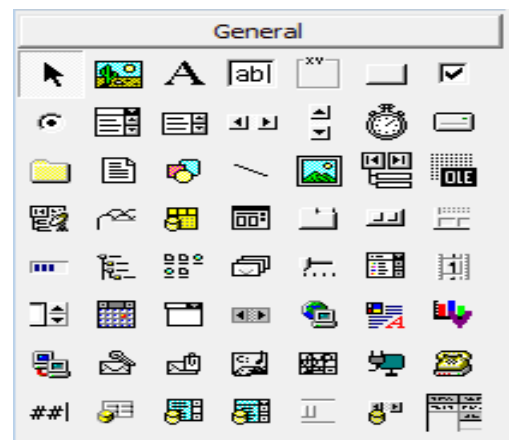

Gambar 6. Tampilan Toolbox pada Visual Basic 6.0

6) Properties Windows

Adalah sebuah jendela yang mengandung semua informasi mengenai objek yang terdapat pada aplikasi Visual Basic. Properti adalah sifat dari sebuah objek, misalnya seperti nama, warna, ukuran, posisi dan sebagainya. 


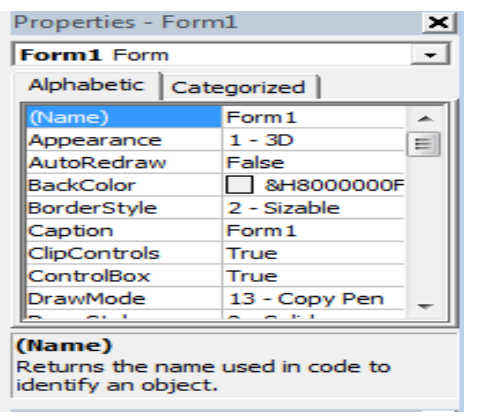

Gambar 7. Tampilan Properties Window pada Visual Basic 6.0

\section{7) Code Editor}

Code Editor disebut juga jendela kode adalah salah satu item terpenting dalam pemrograman Visual Basic. Jendela ini berisi kode-kode program yang merupakan instruksi untuk aplikasi Visual Basic agar dijalankan seperti menutup aplikasi, membatalkan perintah, mengaktifkan salah satu objek dan sebagainya.

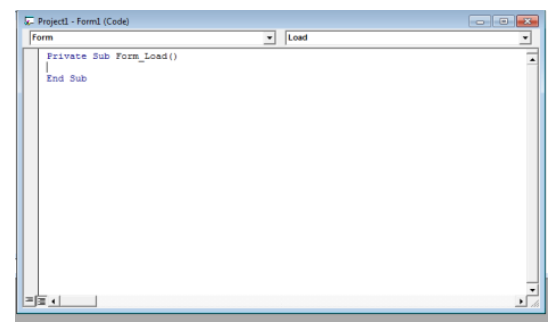

Gambar 8. Tampilan code editor pada Visual Basic 6.0

\section{8) Form Layout Window}

Form Layout Window berfungsi untuk menetapkan posisi tampilan program ketika dijalankan. Posisi pada Form layout window inilah yang merupakan petunjuk di mana aplikasi akan ditampilkan pada layar monitor saat dijalankan.

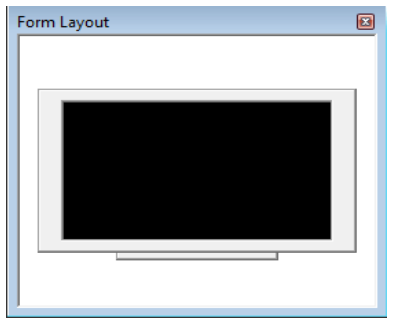

\section{Gambar 9. Tampilan form layout window}

\subsection{Flowchart}

Menurut Anharku (2009). Flowchart adalah penyajian yang sistematis tentang proses dan logika dari kegiatan penanganan informasi atau penggambaran secara grafik dari langkah-langkah dan urut-urutan prosedur dari suatu program. Flowchart menolong analis dan programmer untuk memecahkan masalah kedalam segmen-segmen yang lebih kecil dan menolong dalam menganalisis alternatif-alternatif lain dalam pengoperasian.
Tabel 7. Simbol - Simbol Flowchart

\begin{tabular}{|c|c|c|c|}
\hline NO & SIMBOL & NAMA & FUNGSI \\
\hline 1 & & Terminator & $\begin{array}{r}\text { Permulaan / } \\
\text { akhir program }\end{array}$ \\
\hline 2 & & $\begin{array}{c}\text { Garis Alir (Flow } \\
\text { Line) }\end{array}$ & $\begin{array}{c}\text { Arah aliran } \\
\text { program }\end{array}$ \\
\hline 3 & & Preperation & $\begin{array}{l}\text { Proses } \\
\text { inisialisasi / } \\
\text { pemberian } \\
\text { harga awal } \\
\end{array}$ \\
\hline 4 & & Proses & $\begin{array}{c}\text { Proses } \\
\text { perhitungan / } \\
\text { proses } \\
\text { pengolahan } \\
\text { data }\end{array}$ \\
\hline 5 & & $\begin{array}{c}\text { Input / Output } \\
\text { data }\end{array}$ & $\begin{array}{c}\text { Proses input / } \\
\text { output data, } \\
\text { parameter, } \\
\text { informasi }\end{array}$ \\
\hline 6 & & $\begin{array}{l}\text { Predefined } \\
\text { process (sub } \\
\text { program) }\end{array}$ & $\begin{array}{l}\text { Permulaan sub } \\
\text { program / } \\
\text { proses } \\
\text { menjalankan } \\
\text { sub program }\end{array}$ \\
\hline 7 & & Decision & $\begin{array}{c}\text { Perbandingan } \\
\text { pernyataan, } \\
\text { penyeleksian } \\
\text { data yang } \\
\text { memberikan } \\
\text { pilihan untuk } \\
\text { langkah } \\
\text { selanjutnya }\end{array}$ \\
\hline 8 & & $\begin{array}{l}\text { On Page } \\
\text { Connector }\end{array}$ & \begin{tabular}{|} 
Penghubung \\
bagian-bagian \\
flowchart \\
yang berada \\
pada satu \\
halaman \\
\end{tabular} \\
\hline 9 & & $\begin{array}{l}\text { Off Page } \\
\text { Connector }\end{array}$ & \begin{tabular}{|c|} 
Penghubung \\
bagian-bagian \\
flowchart \\
yang berada \\
pada halaman \\
berbeda \\
\end{tabular} \\
\hline
\end{tabular}

\subsection{Metode Pengujian Sistem}

Menurut Pressman (2007), pengujian menyajikan anomali yang menarik bagi perekayasa perangkat lunak. Pada proses perangkat lunak, perekayasa berusaha membangun perangkat lunak dari konsep abstrak dari implementasi yang dapat dilihat, baru kemudian dilakukan pengujian.

\subsubsection{Pengujian Metode White Box}

Menurut Pressman (2007), pengujian white-box, yang kadang-kadang disebut pengujian glass-box, adalah metode desain test case. Dengan menggunakan metode pengujian white-box, perekayasa sistem dapat melakukan test case yang: 
1. Memberikan jaminan bahwa semua jalur independen pada suatu modul telah digunakan paling tidak satu $\mathrm{kal}$,

2. Menggunakan semua keputusan logis pada sisi true dan false

3. Mengeksekusi semua loop pada batasan mereka dan pada batas operasional mereka

4. Menggunakan struktur data internal untuk menjamin validitasnya.

\subsubsection{Pengujian Metode Black Box}

Menurut Pressman (2007), pengujian black-box berfokus pada persyaratan fungsional perangkat lunak. Dengan demikian, pengujian black-box memungkinkan perekayasa perangkat lunak mendapatkan serangkaian kondisi input yang sepenuhnya menggunakan semua persyaratan fungsional untuk suatu program. Pengujian black-box bukan merupakan alternative dari teknik white-box, tetapi merupakan pendekatan komplementer yang kemungkinan besar mampu mengungkap kelas kesalahan daripada metode white-box. Pengujian blackbox berusaha menemukan kesalahan dalam kategori sebagai berikut:

1. Fungsi-fungsi yang tidak benar atau hilang

2. Kesalahan interface

3. Kesalahan dalam struktur data atau akses database eksternal

4. Inisialisasi dan kesalahan terminasi

\section{RANCANGAN SISTEM/APLIKASI}

Berikut ini adalah flowchart Sistem Pendukung Keputusan Penentuan Supplier Bahan Bangunan:

\subsection{Flowchart Perhitungan Menggunakan Metode SMART}

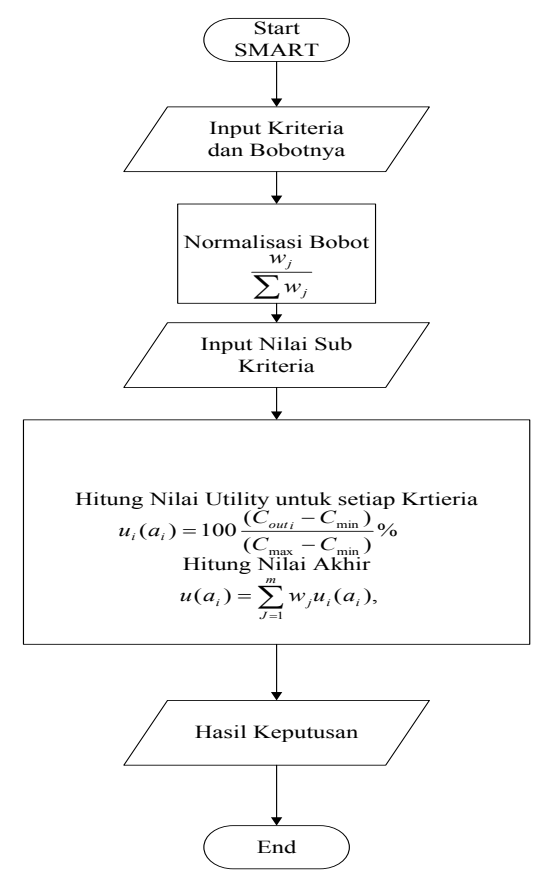

Gambar 10. Flowchart Perhitungan Menggunakan Metode SMART
Dari gambar 10 Flowchart Perhitungan Menggunakan Metode SMART, diawali dengan input kriteria dan bobot, lalu diproses dalam normalisasi bobot, kemudian input nilai sub kriteria, selanjutnya hitung nilai utility setiap sub kriteria dan hitung nilai akhir, kemudian output hasil keputusan, dan selesai.

\subsection{Flowchart Sistem Penentuan Supplier Menggunakan Metode SMART}

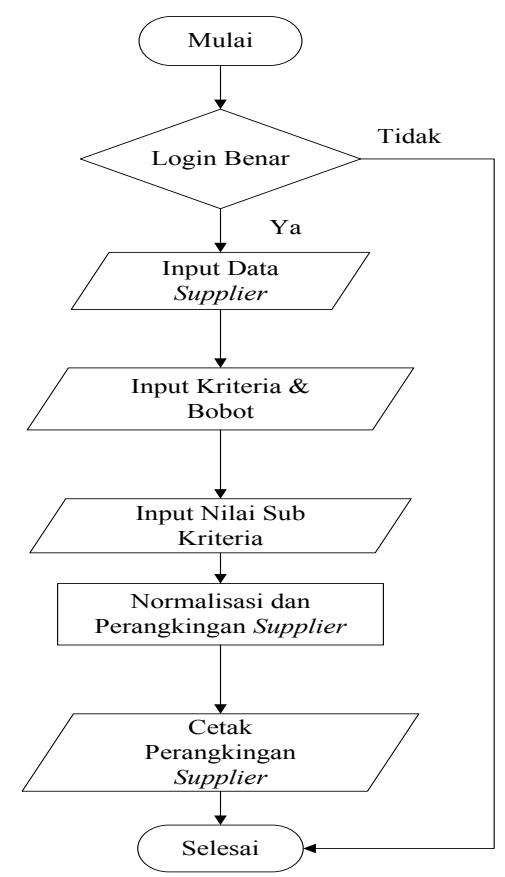

\section{Gambar 11. Flowchart Sistem Penentuan Supplier Menggunakan Metode SMART}

Flowchart sistem penentuan supplier menggunakan metode SMART, diawali dengan login benar, jika login tidak benar maka program akan selesai, jika benar atau ya maka, input data supplier, lalu input kriteria dan bobot, kemudian input nilai sub kriteria, kemudian diproses dalam normalisasi dan perangkingan supplier, kemudian output cetak perangkingan supplier, dan selesai.

\section{IMPLEMENTASI}

Hasil implementasi berdasarkan analisis dan perancangan adalah sebagai berikut:

\subsection{Form Data Kriteria}

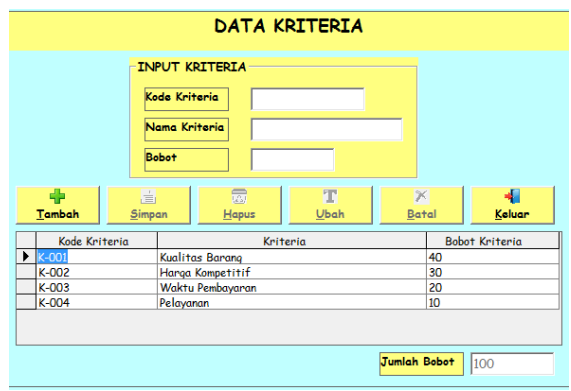

Gambar 12. Form Data Kriteria 


\subsection{Form Data Subkriteria}

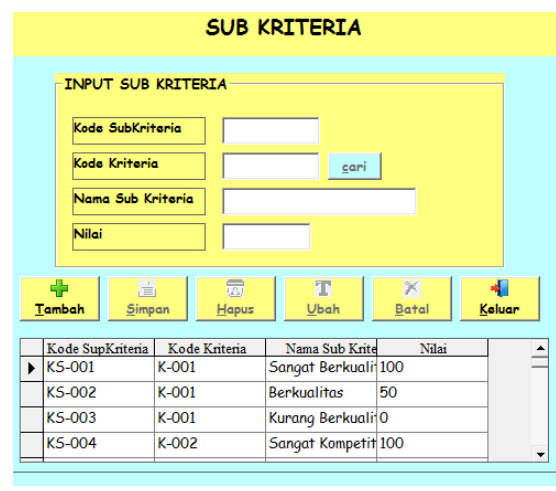

Gambar 13. Form Data Subkriteria

\subsection{Form Penentuan Supplier}

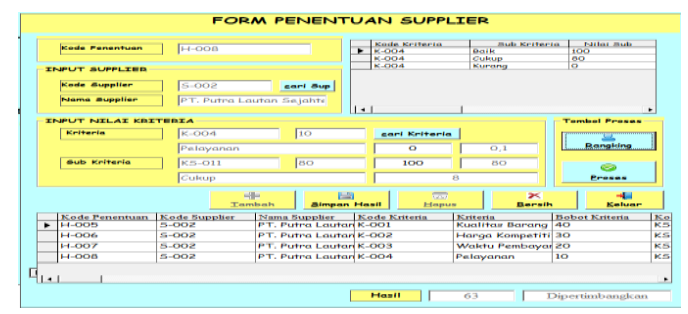

Gambar 14. Form Penentuan Supplier

Form Penentuan supplier adalah proses perhitungan SMART.

\subsection{Form Perangkingan}

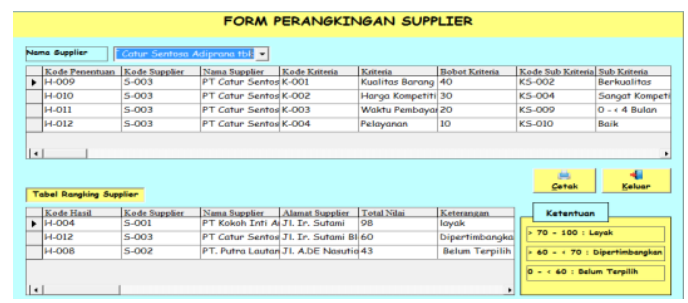

Gambar 15. Form Perangkingan

\section{KESIMPULAN}

Dengan adanya hasil penelitian yang dilaksanakan dan berdasarkan uraian yang telah dibahas pada bab-bab sebelumnya, maka dapat ditarik kesimpulan bahwa :

1. Dengan adanya sistem ini, maka dapat membantu dalam pembelajaran pada mata kuliah sistem pendukung keputusan, terutama pengunaan metode SMART (Simple Multi Attribute Rating Technique) dalam mencari solusi pengambilan keputusan.

2. Adanya 4 kriteria yang digunakan yaitu kriteria kualitas barang memiliki sub kriteria sangat berkualitas, berkualitas dan kurang berkualitas. Kriteria harga kompetitif dengan sub kriteria sangat kompetitif, kompetitif dan kurang kompetitif. Kriteria waktu pembayaran memiliki sub kriteria $\geq 12$ bulan, $\geq 4-<12$ bulan dan $0-<4$ bulan. Kemudian kriteria Pelayanan memiliki sub kriteria baik, cukup, kurang.
3. Dengan adanya sistem pendukung keputusan penentuan supplier pada Toko Bintang Keramik Jaya, dapat membantu pimpinan toko dalam mengambil keputusan yang tepat dalam menentukan supplier, yang dapat diterima sesuai dengan kriteria yang telah ditetapkan Toko Bintang Keramik Jaya.

4. Dapat mempermudah pimpinan toko dalam menentukan perangkingan supplier.

\section{SARAN}

Adapun saran-saran yang dapat dikemukakan yaitu sebagai berikut:

1. Diharapkan bisa memakai metode SPK yang lain , misalnya TOPSIS, K-NN, Electre dan lain-lain

2. Diharapkan sistem pendukung keputusan ini dibuat secara online (website). Sistemnya adalah memudahkan semua pemilik toko bangunan memutuskan supplier yang layak, dipertimbangkan atau belum terpilih. Kemudian memudahkan pemilik toko bangunan akses aplikasi SPK ini tidak hanya disatu tempat, tetapi harus memiliki akses internet.

3. Diharapkan sistem pendukung keputusan ini dibuat secara Android. Sistemnya adalah untuk memudahkan pemilik toko bangunan mengunduh aplikasi melalui playstore atau apk aplikasi SPK ini dapat digunakan untuk smartphone. Pemilik toko bangunan bisa langsung menentukan supplier mana yang layak untuk dipilih, dipertimbangkan atau belum terpilih.

\section{DAFTAR PUSTAKA}

Andi, 2010, Aplikasi Database Visual Basic 6.0 Dengan Crystal Report, Yogyakrta: Andi Offset.

Anharku. 2009. Flowchart. http://ilmukomputer.org/wpcontent/uploads/2009/06/anharku-flowchart.pdf. (diakses 01 Desember 2015)

Jogiyanto, HM, 2008, Analisis \& Desain Sistem Informasi, Yogyakarta: Andi Offset.

Kusrini, 2007, Konsep dan Aplikasi Sistem Penunjang Keputusan, Yogyakarta: Andi.

Kustiyahningsih Yeni, Devie Rosa Anamisa, \& Nikmatus Syafa'ah. 2013. Sistem Pendukung Keputusan Untuk Menentukan Jurusan Pada Siswa SMA Menggunakan Metode KNN dan SMART. https://yenikustiyahningsih.files.wordpress.com/20 13/04/knn.docx. (diakses 1 November 2015)

Pressman, Roger, 2007, Rekayasa Perangkat Lunak, Yogyakarta: Andi Offset.

Madcoms, 2010, Microsoft Access 2010 Untuk Pemula, Yogyakarta: Andi Offset.

Subari, dan Yustanto, 2008, Pemrograman Microsoft Visual Basic 6.0., Jakarta: PT. Elex Media Komputindo. 
